Рекомендована д. фрармац. наук, профр. Д. І. Дмитрієвським

УДК 616.453.014.64

DOI 10.11603/2312-0967.2017.2.7907

\title{
СУЧАСНИЙ СТАН СТВОРЕННЯ, ВИРОБНИЦТВА ТА ДОСЛІДЖЕННЯ ШВИДКОРОЗЧИННИХ ОРАЛЬНИХ ПЛІВОК
}

\author{
() М. Б. Демчук ${ }^{1}$, Ю. Я. Мельник ${ }^{2}$, Т. А. Грошовий ${ }^{1}$, В. Й. Скорохода ${ }^{2}$, А. І. Денис ${ }^{1}$ \\ ${ }_{1}^{1}$ ДВНЗ «Тернопільський державний медичний університет імені І. Я. Горбачевського \\ МОЗ України» \\ ${ }^{2}$ Національний університет «Львівська політехніка» \\ pavljukm@tdmu.edu.ua
}

\begin{abstract}
Мета роботи. Опрацювати та узагальнити літературні дані щодо основних характеристик, особливостей технології, можливостей використання швидкорозчинних оральних плівок.

Матеріали і методи. Огляд літератури про лікарську форму - швидкорозчинні оральні плівки.

Результати й обговорення. Швидкорозчинні оральні плівки являють собою дуже тонку плівку площею 5-20 см², яку пацієнт може поміщати на язик або слизову оболонку у ротовій порожнині. Слина, що змочує плівку, приводить до їі швидкої гідратації і прилипання до місця застосування. Рецептура швидкорозчинних оральних плівок складається із діючих речовин, водорозчинних полімерів, пластифікаторів, підсолоджувачів, ароматизаторів, речовин, що стимулюють слиновиділення. Для виготовлення плівок використовують метод виливання 3 випаровуванням розчинника, напівтвердого виливання, гарячої екструзії розплаву, роликового ущільнення. Для оцінки якості плівок визначають механічні показники, органолептичні характеристики, рН поверхні плівки, прозорість, однорідність вмісту, розпадання, розчинення, кількісне визначення.

Висновки. Розглянуто основні характеристики, особливості технології, можливості використання плівок, що здатні прикріплюючись до слизової оболонки рота швидко вивільняти лікарські речовини.
\end{abstract}

Ключові слова: швидкорозчинні оральні плівки; ротова порожнина; технологія виготовлення; полімери.

Вступ. Швидкорозчинні системи доставки лікарських речовин (ЛР) були розроблені в кінці 1970 років як альтернатива таблеткам, капсулам, сиропами для застосування педіатричними та геріатричними пацієнтами. Швидкорозчинні оральні лікарські фрорми, за визначенням, при потраплянні у ротову порожнину швидко розчиняються чи розпадаються з утворенням розчину або суспензії без необхідності додавання води. Порожнина рота створює унікальне середовище для доставки лікарських засобів. Слизова оболонка порожнини рота забезпечує прямий доступ ЛР в системний кровотік, уникаючи першого рівня метаболізму. Дослідження у напрямку створення систем доставки ЛР у ротовій порожнині дозволили розробити технологію швидкорозчинних ородисперсних таблеток, капсул та плівок [1].

Основною перевагою використання швидкорозчинних оральних форм $€$ можливість їх приймання пацієнтами, що страждають від дисфагії. За оцінками, 35 \% від загальної чисельності населення, а це 30 - 40 \% літніх пацієнтів, страждають від диссрагії. Цей розлад пов'язаний з багатьма захворюваннями, включно інсульт, хворобу Паркінсона, СНІД, тиреоїдектомію, променеву терапію, неврологічні розлади, в тому числі церебральний параліч [2].
Швидкорозчинні оральні плівки (ШОП) представляють собою дуже тонку плівку площею 5-20 см², яку пацієнт може поміщати на язик або слизову оболонку у ротовій порожнині. Слина, що змочує плівку, призводить до швидкої її гідратації і прилипання до місця застосування. ШОП були розроблені на основі технології трансдермального пластиру.

Переваги оральних плівок:

- доступні у різних розмірах і формах, тонкі;

- характеризуються відмінною мукоадгезією;

- швидко розчиняються протягом декількох хвилин у роті;

- не потребують води для ковтання;

- дозволяють маскувати смак;

- майже не залишають залишку у роті;

- еорективні для забезпечення швидкого початку дії при раптових епізодах алергічного нападу або кашлі, бронхітах, астмах;

- характеризуються підвищеною біодоступністю, особливо у випадках, не розчинних і гідросообних ЛР, через швидкий розпад і розчинення;

- підвищують комплаєнс пацієнта.

Основними недоліками оральних плівок $€$ те, що у їх склад не можуть вводитися ЛР, які є нестабільними при рН ротової порожнини, подразнюють слизову

ISSN 2312-0967. Pharmaceutical review. 2017. № 2 
оболонку чи мають гіркий смак, не можуть вводитися ЛР у великих дозах; плівки потребують спеціальної упаковки з метою захисту від води та ударів [3].

Бажаними характеристиками молекули лР для введення у плівку є:

- вміст не повинен перевищувати 40 мг;

- при рН ротової порожнини молекули повинні бути в недисоційованому стані;

- має бути стабільною і розчинною у воді;

- повинна мати приємний смак;

- має бути здатною проникати через слизову оболонку рота [4].

Рецептура оральних плівок включає складне поєднання таких естетичних і експлуатаційних характеристик, як маскування смаку, швидке розчинення зовнішній вигляд, відчуття в роті і т.д. Негайне розчинення, у воді або слині досягається за допомогою спеціальної матриці з водорозчинних полімерів. Композиція плівок складається із: ЛР (1-25\%), водорозчинних полімерів (40-50\%), пластифікаторів (0$40 \%)$, наповнювачі, ароматизатори та ін. (0-40\%) [5].

\section{Активні фрармацевтичні інгредієнти (АФІ)}

лР може належати до будь-якого класу АФІ для введення перорально або через слизову оболонку рота відповідно. За літературними даними, АФІ можуть бути додані у кількості 5 - 25 \% від загальної маси полімеру. Для ефективної розробки доза препарату повинна бути менша 20 мг/добу. Перспективними для розробки швидкорозчинних плівок $є$ ЛР, які використовуються у педіатрії (протикашльові, відхаркувальні, антиастматичні), геріатрії (протиепілептичні, відхаркувальні), у лікуванні шлунково-кишкових захворювань, нудоти (наприклад, внаслідок цитостатичної терапії), мігрені, захворювань центральної нервової системи.

Для розробки оральних плівок використовують такі ЛР, як хлорореніраміну малеат, бромфеніраміну малеат, дексхлорфенірамін, трипролідину гідрохлорид, акривастин, азатадину малеат, лоратидин, френілесрину гідрохлорид, декстрометорфану гідрохлорид, кетопрофен, суматриптану сукцинат, золмитриптан, лоперамід, фрамотидин, омепразол, сальбутамолу сульфрат, парацетамол, мелоксикам, нікотин, кофреїн, дисренгідраміну гідрохлорид, псевдоефедрину гідрохлорид [6].

Полімери використовують як носії ЛР. Як плівкоутворювачі зазвичай використовують гідрофрільні полімери, зокрема похідні полімерів целюлози, такі як гідроксипропілметилцелюлоза (ГПМЦ), гідроксипропілцелюлоза і натрій карбоксиметилцелюлоза (натрій КМЦ) різних марок, а також натрію альгінат, полівінілпіролідон (ПВП), поліетиленгліколь (ПЕГ). Плівки не повинні пошкоджуватися при транспортуванні чи в обігу. Межа міцності на розрив залежить від типу і кількості полімеру, що використовується у плівці $[7,8]$.
Пластифрікатори покращують плівкоутворюючі властивості плівки, зменшують температуру склування полімеру. Вибір пластиорікаторів залежить від сумісності з полімером, методу формування плівки і природи розчинника. Одними з найбільш часто використовуваних пластифікаторів $€$ гліцерин, пропіленгліколь, низькомолекулярний ПЕГ, похідні фрталатів, такі як диметил-, діетил- і дибутилорталат, трибутил-, триетилцитрат, ацетил цитрат, триацетин і рицинова олія. Зазвичай пластифрікатори використовуються в концентрації до 20 \% від ваги сухого полімеру. Проте неправильне використання пластифікатора може привести до розтріскування плівки $[9,10]$.

При розробці складу ШОП дицикломіну використання пластифрікатора ПЕГ 400 покращувало фрізикохімічні параметри плівки, зокрема міцність при розтягуванні, відносну елонгацію, гнучкість [11].

Підсолоджувачі $€$ важливими компонентами плівок, які призначені для розпадання або розчинення у ротовій порожнині. Зазвичай підсолоджувачі використовуються в концентрації від 3 до $6 \%$. У технології плівок використовуються натуральні та штучні підсолоджувачі. Поліспирти, такі як сорбіт, маніт, ізомальт також можуть бути використані у складі плівок, оскільки вони додатково забезпечують хороше відчуття у ротовій порожнині. Однак слід зазначити, що введення природних цукрів у такі препарати зумовлює обмежене їх використання пацієнтами, які знаходяться на дієті або хворіють на цукровий діабет. 3 цієї причини набули популярності штучні підсолоджувачі, зокрема сахарин, цикламат, аспартам, ацесульфам-К, сукралоза, алітам і неотам [10]. Аспартам та ментол використовували у технології оральних плівок вальдекоксибу [12].

Для маскування гіркого смаку диклофенаку натрію у плівках використовували комбінацію ароматизаторів м'яти та солодки із сукралозою. Додавання цієї комбінації істотно не впливає на час розпадання (1520 с) і швидкість розчинення плівки (близько 5 хв) [13].

Речовини, що стимулюють слиновиділення вводять у склад швидкорозчинних плівок 3 метою збільшення швидкості виробництва слини, а отже, швидшого розпадання плівки. Як стимулятори слиновиділення використовують лимонну, яблучну, молочну, аскорбінову і винну кислоти. Ці речовини використовують окремо або в комбінації від 2 до 6 \% від маси плівки [14].

Ароматизатори. Сприйняття пацієнтом лікарської форми також залежить від вихідного аромату, який спостерігається в перші кілька секунд після використання, і смаку препарату, який залишається у ротовій порожнині протягом 10 хв. Вибір аромату залежить від типу ЛР, яка включена у композицію. Досліджено, що населення старшого віку надає перевагу запаху м'яти або апельсина. Молоде покоління краще сприймає смак фрруктів, малини і т. д. Ароматизатори

ISSN 2312-0967. Фармацевтичний часопис. 2017. № 2 
можуть бути використані окремо або в комбінації у кількості до 10 \%. Також у склад плівок можуть вводити барвники у кількості до 1 \% [15].

Для виготовлення плівок можуть використовуватися декілька методів.

Метод виливання з випаровуванням розчинника. У воду чи суміш інших розчинників додаються допоміжні речовини, утворений розчин нагрівають до $60{ }^{\circ} \mathrm{C}$, додають водорозчинні полімери, охолоджують утворений розчин до кімнатної температури, додають ЛР, перемішують 3 утворенням однорідного розчину. Утворений розчин відливають у чашки Петрі і висушують $[15,16]$.

Розроблено швидкорозчинні сублінгвальні плівки ризатриптану бензоату для лікування мігрені. У складі плівок як плівкоутворюючий полімер використано комбінацію ГПМЦ Е 15 та мальтодекстрину, як дезінтегрант - натрію крохмаль гліколят, як охолоджуючу, підсолоджуючу речовини - гліцерол, аспартам, натрію лаурил сульфрат. Час розчинення отриманих плівок становив 25-50 с [17].

Проведено дослідження з розробки складу шОП антихолінергічного препарату дицикломіну. Оптимальний склад плівок, який отримано при використанні полінілового спирту (ПВС), ПЕГ 400, аспартаму, лимонної кислоти, ментолу та твіну 80, забезпечував мінімальні значення розпадання, розчинення, вивільнення 94,1376 \% ДР протягом 5 хв [11].

Обґрунтовано склад і технологію отримання ШОП діазепаму з використання ГПМЦ Е5 та ПЕГ 400. Вивільнення ДР становило 99,89 \% протягом 15 хв, що $€$ значно вищим порівняно з вивільненням діючої речовини (ДР) із таблеток Валіум (68,81 \%) [18].

Отримано ШОП золмітриптану методом виливання 3 випаровуванням розчинника. Оптимальний склад плівок, що містив натрію альгінат, натрію крохмаль гліколят, ПЕГ 400, ванілін, натрію сахарин забезпечував вивільнення 98,5 \% ДР протягом 6 хв [19].

Розроблено шОП ондасетрону гідрохлориду для сублінгвального застосування. При розробці складу плівок досліджували такі полімери, як ПВС, ПВП, карбопол 934Р у різних співвідношеннях; пластифікатори - пропіленгліколь або ПЕГ 400, підсолоджувачі - маніт або сахарин натрію. У дослідженнях in vitro спостерігали 81-96 \% вивільнення ДР протягом 7 хв i 66-80 \% протягом 7 хв у дослідженнях ex vivo. Більш високий відсоток вивільнення ДР спостерігали з плівок, що містили підсолоджувачі [20].

При досліджені складу ШОП гранісетрону гідрохлориду кращі результати отримано при використанні ГПМЦ 15 cps (у кількості 45-50%), пропіленгліколю (15-20 \%), сахарину натрію, ароматизатора м'яти [21].

Метод напівтвердого виливання. Цей метод переважно застосовується тоді, коли у композицію плівок введені не розчинні у кислотах полімери. Гель масу відливають у плівки за допомогою барабанів, які нагріваються. Гель масу отримують шляхом додавання плівкоутворюючого розчину до розчину кислото-нерозчинного полімеру у гідроксиді натрію. Кислото-нерозчинні полімери, використовувані для отримання плівок, включають ацетат-срталат целюлози, ацетат бутират целюлози. Кислото-нерозчинні полімери і плівкоутворювальні полімери повинні використовуватися у співвідношенні (1: 4) [9].

Метод гарячої екструзії розплаву. ЛР змішують 3 допоміжними речовинами у твердій формі. Потім висушений гранульований матеріал вводять в екструдер. Швидкість шнека слід встановити на рівні 15 об/хв, щоб обробити гранули протягом 3-4 хв. Екструдат (3 температурою $65^{\circ} \mathrm{C}$ ) пресують для отримання плівки [10].

Метод роликового ущільнення (компактування). Розчин або суспензію ЛР з плівкоутворюючим полімером подають на роликове ущільнення. Розчин або суспензія повинна мати певні реологічні характеристики. Розчинник являє собою воду або суміш води і спирту. Плівку сушать на валках і нарізають до бажаних фрорм і розмірів [14].

Для оцінки якості плівок використовують наступні показники $[2,10]$ :

- механічні показники: товщина, міцність при розтягуванні, відносне видовження при розриві, еластичність.

- органолептичні характеристики;

- тест на набухання;

- дослідження рН поверхні плівки;

- прозорість;

- однорідність вмісту ДР;

- розпадання;

- розчинення;

- кількісне визначення ДР.

Для еластичних полімерних лікарських плівок досліджували деформаційно-пружні (числа твердості, пружності і пластичності) та десормаційно-міцнісні (межа міцності при розтягуванні, відносне видовження при розриві, межа міцності при прориві, відносне видовження при прориві) характеристики плівок [22].

Запатентовані технології ШРП:

1. Soluleaves-технологія представляє плівки для швидкого розчинення при контакті зі слиною і вивільнення ЛР. Ці системи можуть бути використанні для лікування кашлю, простуди, больових симптомів, захворювань шлунково-кишкового тракту, а також доставки поживних речовин. Soluleaves плівки також можуть бути розроблені з метою вивільнення ДР повільно протягом 15 хв [23].

2. Wafertab плівки, у яких АФІ точно дозований і інтегрований в тіло попередньо виготовленої плівки XGEL, для запобігання руйнівного впливу тепла і вологи i, можливо, підвищення стабільності продукту. Wafertab можуть бути отримані різних фрорм і розмірів і $є$ ідеальним способом введення лікарських речовин,

ISSN 2312-0967. Pharmaceutical review. 2017. № 2 
які вимагають швидкого вивільнення, або для використання пацієнтами, які мають труднощі з ковтанням.

3. Foamburst $€$ спеціальним видом Soluleaves технології, де інертний газ вводиться у плівку під час виробництва. У результаті утворюються плівки з комірчастою структурою, яка забезпечує швидке розчинення і приємне відчуття у ротовій порожнині [24].

4. XGEL плівки $€$ інтелектуальною власністю компанії Meldex International і використовуються для введення фрармацевтичних та інших речовин. Назва «XGEL» походить від скорочення «без желатину». XGEL плівки забезпечують унікальні переваги продукту, не мають тваринного походження, розглядаються як безпечні, оскільки отримані на основі целюлози (ГПМЦ, ГЕЦ, КМЦ і т.Д.) і фрруктових кислот (лимонна кислота). Таким чином, вони можуть використовуватися особами 3 різними релігійними переконаннями і вегетаріанцями. Вони застосовуються як носії для ароматизаторів, вітамінів, мінералів, харчових добавок і фрармацевтичних речовин. Плівки XGEL здатні мати ентеросолюбільні властивості, в той же час маючи можливість включати ЛР. Системи XGEL Moжуть інкапсулювати будь-яку пероральну лікарську форму, бути розчинними в холодній або гарячій воді. Плівки XGEL отримують методом виливання. На основі плівки XGEL тм розроблено вторинні технології з виробництва капсул, покриття таблеток і інкапсулювання пастилок. Ці продукти і процеси запатентовані як TabWrap, NRobe, Meltums, Septum ta Swollo [25].

На світовому фрармацевтичному ринку доступні декілька різновидів ШОП, зокрема:
- компанією MonoSolRx запропоновано на ринок плівки декстрометорфану гідроброміду, дисенгідраміну цитрату, плівки для свіжого подиху [26];

- фрірмою Labtec Pharma зареєстровано швидкорозчинні плівки донепезілу для лікування хвороби Альцгеймера та ондасетрону [27];

- плівки ротавірусної вакцини для дітей, виготовлені Johns Hopkins undergraduate biomedical engineering students [28];

- компанією Hughes medical corporation розроблені шОП метилкобаламіну, дифемгідраміну гідрохлориду, декстрометорфану, фолієвої кислоти, кофреїну [29];

- плівки 3 корицею, з вітаміном С, плівки охолоджуючі з перцевою м'ятою, а також плівки з бензокаїном, кофреїном виготовлені компанією Dow chemical company [30];

- освіжаючі плівки Listerine PocketPaks запропоновані фрірмою Pfizer's Warner-Lambert consumer healthcare division [31];

- енергетичні плівки 3 кофеїном 20 мг, плівки 3 ацетилсаліциловою кислотою, а також шОП ондасетрону гідрохлориду, дексаметазону, нітрогліцерину, вітаміну $\mathrm{B}_{12}$, мелатоніну, фролієвої кислоти, бензокаїну, диоремгідраміну гідрохлориду, декстрометорфану запропоновано на ринок компанією ODF Technologies Inc [32].

Висновки. Розглянуто основні характеристики, особливості технології, можливості використання плівок, що здатні прикріплюючись до слизової оболонки рота швидко вивільняти лікарські речовини.

\title{
СОВРЕМЕННОЕ СОСТОЯНИЕ СОЗДАНИЯ, ПРОИЗВОДСТВА И ИССЛЕДОВАНИЯ БЫСТРОРАСТВОРИМЫХ ОРАЛЬНЫХ ПЛЕНОК
}

\author{
М. Б. Демчук ${ }^{1}$ Ю. Я. Мельник², Т. А. Грошовый ${ }^{1}$ В. И. Скорохода², А. И. Денис ${ }^{1}$

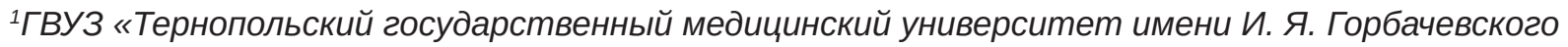 \\ МЗ Украины» \\ 2Национальный университет «Львовская политехника» \\ pavljukm@tdmu.edu.ua
}

Цель работы. Разработать и обобщить литературные сведения относительно основных характеристик, особенностей технологии, возможностей использования быстрорастворимых оральных пленок.

Материалы и методы. Обзор литературы о лекарственной фрорме - быстрорастворимые оральные пленки.

Результаты и обсуждение. Быстрорастворимые оральные пленки представляют собой очень тонкую пленку площадью 5-20 см², которую пациент может помещать на язык или слизистую оболочку ротовой полости. Слюна, смачивает пленку, ведет к быстрой ее гидратации и прилипания к месту применения. Рецептура быстрорастворимых оральных пленок состоит из действующих веществ, водорастворимых полимеров, пластификаторов, подсластителей, ароматизаторов, веществ, которые стимулируют выделения слюни. Для изготовления пленок используют метод литья с испарением растворителя, полутвердого литья, горячей экструзии расплава, роликового уплотнения. Для оценки качества пленок определяют механические показатели, органолептические характеристики, рН поверхности пленки, прозрачность, однородность содержания, распад, растворение, количественное определение.

Выводы. Рассмотрены основные характеристики, особенности технологии, возможности использования пленок, которые способны прикрепляясь к слизистой оболочке рта быстро высвобождать лекарственные вещества.

ISSN 2312-0967. Фармацевтичний часопис. 2017. № 2 


\title{
MODERN STATE OF CREATION, PRODUCTION AND RESEARCH OF FAST DISSOLVING ORAL FILMS
}

\author{
M. B. Demchuk, Yu. Ya. Melnyk ${ }^{1}$, T. A. Hroshovyi, V. J. Skorokhoda ${ }^{1}$, A. I. Denys ${ }^{1}$ \\ I. Horbachevsky Ternopil State Medical University \\ ${ }^{1}$ Lviv Polytechnic National University \\ pavljukm@tdmu.edu.ua
}

The aim of the work. The literature data on the basic characteristics, features of technology, opportunities of use fast dissolving oral films were studied and summarized.

Materials and Methods. Literature review of dosage form - fast dissolving oral film.

Results and Discussion. Fast dissolving oral film is a very thin film with area of $5-20 \mathrm{~cm}^{2}$, which the patient can placed on the tongue or the mucous membrane in the mouth. Saliva, which wets the film, leads to rapid hydration and it adhesion to the place of use. Composition of fast dissolving oral films is consisting of active pharmaceutical ingredients, water-soluble polymers, plasticizers, sweeteners, flavors, saliva stimulating agents. The following processes can be used to manufacture the oral fast dissolving films: solvent casting method, semisolid casting, hot-melt extrusion method, rolling method. To evaluate the quality of films, mechanical properties, organoleptic characteristics, $\mathrm{pH}$ of film surface, transparency, uniformity of content, disintegration, dissolution, quantitative determination are determined.

Conclusions. The main characteristics, technology, and the possibility of using films those are capable of attaching to the oral mucosa rapidly releasing drugs were considered.

Key words: fast dissolving oral film; mouth; technology of manufacturing; polymers.

\section{Список літератури}

1. Sastry S. V. Recent technological advances in oral drug delivery. A review / S. V. Sastry, J. R. Nyshadham, J. A. Fix // Pharm. Sci. Technol. Today. - 2000. - Iss. 3. - P.138-145. 2. Orally fast dissolving films: innovations in formulation and technology. / B. Bhupinder, J. Sarita, K. Mandeep [et al.] // Int. J. Pharm. Sci. Rev. Res. - 2011. - Vol. 9, Iss. 2. - P.50-57.

3. Deepak Heer Recent trends of fast dissolving drug delivery system - an overview of formulation technology / Deepak Heer, Geeta Aggarwal, S. L. Hari Kumar // Pharmacophore. - 2013. - Vol. 4 (1). - P. 1-9.

4. Fast dissolving oral films technology: a recent trend for an innovative oral drug delivery system / Deepak Sharma, Daljit Kaur, Shivani Verma [et al.] // Int. J. of Drug Delivery. - 2015. - Iss. 7 (2). - P. 60-75.

5. Chonkar Ankita D. An overview on fast dissolving oral films / D. Chonkar Ankita, S. T. Bhagawati, N. Udupa // Asian J. Pharm. Tech. - 2015. - Iss. 5 (3). - P. 129-137.

6. Alpesh R. Patel Fast dissolving films $\left(\right.$ FDF $\left._{\mathrm{s}}\right)$ as a newer venture in fast dissolving dosage forms / Alpesh R. Patel, Dharmendra S. Prajapati, Jignyasha A. Raval // Int. J. Drug Dev. \& Res. - 2010. - Iss. 2 (2). - P. 232-246.

7. Exploration of film forming properties of film formers used in the formulation of rapid dissolving films. / Dhagla Ram Choudhary, Vishnu Patel, Harsha Patel [et al.] // Int. J. Chemtech. Res. - 2011. - Iss. 3 (2). - P. 531-533.

8. Freny Hirpara Optimization \& screening of different film forming polymers and plasticizers in fast dissolving sublingual film / Freny Hirpara, Sujit Kumar Debnath, S. Saisivam // Int. J. Pharm. Pharm. Sci. - 2014. - Iss. 6 (6). - P. 41-42. 9. Ankita Keshari. Fast dissolving oral film: a novel and innovative drug delivery system. / Ankita Keshari, Pramod Kumar Sharma, M. Nayyar Parvez // Int. J. of Pharm. Sci. and Res. - 2014. - Iss.5 (3). - P. 92-95.

10. Fast dissolving oral films: an innovative drug delivery system and dosage form / Arun Arya, Amrish Chandra, Vijay Sharma [et al.] // Int. J. Chemtech. Res. - 2010. Iss. 2 (1). - P. 576-583.

11. Formulation and evaluation of fast dissolving oral film of dicyclomine as potential route of buccal delivery / Alka Tomar, Kiran Sharma, Nitesh S Chauhan [et al.] // Int. J. Drug Dev. \& Res. - 2012. - Iss. 4 (2). - P. 408-417.

12. Development of taste masked film of valdecoxib for oral use / R. Sharma, P. K. Parikh, M. C. Gohel [et al.] // Indian J. Pharm. Sci. - 2007. - Iss. 69 (2). - P. 320-323.

13. Diclofenac fast-dissolving film: suppression of bitterness by a taste-sensing system / F. Cilruzo, E. I. Cupone, P. Minghetti [et al.] // Drug Dev. Ind. Pharm. - 2011. Iss. 37 (3). - P. 252-259.

14. Overview on fast dissolving films / Gavaskar Basani, Kumar Subash Vijaya, Guru Sharan [et al.] // Int. J. Pharm. Pharm. Sci. - 2009. - Iss. 2(3). - P. 2933.

15. Fast dissolving oral films: a novel approach to oral drug delivery / Aggarwal Jyoti, Singh Gurpreet, Saini Seema [et al.] // Int. Res. J. of Pharm. - 2011. - Iss. 2 (12). - P. 69-74. 16. A novel approach for buccal drug delivery system fast dissolving film / Gunjan Shrivastava, Pankaj Kumar Singh, Roshni Fatima Rizvi [et al.] // World journal of pharmacy and pharmaceutical sciences. - 2015. - Iss. 4(10). - P.1744-1760.

17. Bhyan Bhupinder Formulation and evaluation of fast dissolving sublingual films of Rizatriptan Benzoate / Bhyan

ISSN 2312-0967. Pharmaceutical review. 2017. № 2 
Bhupinder, Jangra Sarita // Int. J. Drug Dev. \& Res. - 2012. - Iss. 4 (1). - P. 133-134.

18. Formulation and evaluation of fast dissolving oral films of diazepam / M. S. Ali, C. Vijendar, S. D. Kumar [et al.] // J. Pharmacovigilance. - 2016. - Iss. 4 (3). - P. 210.

19. Deepthi A. Formulation and evaluation of fast dissolving oral films of Zolmitriptan / A. Deepthi, B. Venkateswara Reddy, K. Navaneetha // American Journal of Advanced Drug Delivery. - 2014. - Iss. 2 (2). - P.153-163.

20. Koland M. Fast dissolving sublingual films of ondansetron hydrochloride: effect of additives on in vitro drug release and mucosal permeation / M. Koland, V. P. Sandeep, N. R. Charyulu // J. Young Pharm. - 2010. - Iss. 2 (3). - P. 216-222.

21. Development and optimization of fast dissolving orodispersible films of granisetron $\mathrm{HCl}$ using Box-Behnken statistical design / Hema Chaudhary, Samita Gauri, Permender Rathee [et al.] // Bulletin of Faculty of Pharmacy, Cairo University. - 2013. - Iss. 51(2). - P.193-201.

22. Вивчення деформаційно-механічних властивостей стоматологічних лікарських плівок полімерного типу

/ І. С. Гриновець, Т. Г. Калинюк, Ю. Я. Мельник [та ін.] // Фармац. журнал. - 2009. - № 5. - С. 123-128.

23. Режим доступу: http://www.in-pharmatechnologist.com/ Ingredients/BioProgress-uses-films-in-drug-delivery

24. An overview on rapid dissolving films / Prasanna Kumar Desu, B. Brahmaiah, A.Nagalakshmi [et al.] // Asian J. Pharm. Res. - 2013. - Iss.3 (1). - P. 15-23.

25. Режим доступу: http://ddm.staging01.azuragroup. com/@offers/dds/view/905

26. Режим доступу: http://www.monosolrx.com/products.html 27. Режим доступу: http://www.tesa-labtec.com/eng

28. Режим доступу: https://medicalxpress.com/ news/2007-05-students-oral-quick-dissolve-rotavirus-vaccine.html

29. Режим доступу: http://www.smilox.com/smile/ora-filmpain-relief-strips-6pk.cfm

30. Режим доступу: http://www.monosolrx.com/advantages.html

31. Режим доступу: http://www.helikon.com.tr/strip.asp

32. Режим доступу: http://www.odftechnologies.com

\section{References}

1. Sastry SV, Nyshadham JR, Fix JA. Recent technological advances in oral drug delivery. A review. Pharm. Sci. Technol. Today. 2000;3: 138-145.

2. Bhupinder B, Sarita J, Mandeep K, Harmanpreet S. Orally fast dissolving films: innovations in formulation and technology. Int J Pharm Sci Rev Res. 2011; 9(2): 50-7.

3. Deepak Heer, Geeta Aggarwal, SL Hari Kumar. Recent trends of fast dissolving drug delivery system - an overview of formulation technology. Pharmacophore. 2013;4(1): 1-9. 4. Deepak Sharma, Daljit Kaur, Shivani Verma, Davinder Singh, Mandeep Singh, Gurmeet Singh et al. Fast dissolving oral films technology: a recent trend for an innovative oral drug delivery system. Int J Drug Delivery. 2015;7(2): 60-75.

5. Chonkar Ankita D, Bhagawati ST, Udupa N. An overview on fast dissolving oral films. Asian J Pharm Tech 2015;5(3): 129-137. Available from: http://dx.doi.org/10.5958/22315713.2015.00020.3

6. Patel R, Prajapati S, Raval A. Fast dissolving films $\left(\mathrm{FDF}_{\mathrm{S}}\right)$ as a newer venture in fast dissolving dosage forms. Int J Drug Dev \& Res. 2010;2(2): 232-246

7. Dhagla Ram Choudhary, Vishnu Patel, Harsha Patel, Aliasgar $\mathrm{J}$ Kundawala. Exploration of film forming properties of film formers used in the formulation of rapid dissolving films. Int J Chemtech Res. 2011;3(2): 531-533.

8. Hirpara Freny, Kumar Debnath Sujit, Saisivam S. Optimization \& screening of different film forming polymers and plasticizers in fast dissolving sublingual film. Int $\mathrm{J}$ Pharm Pharm Sci. 2014;6(6):41-2.

9. Ankita Keshari, Pramod Kumar Sharma, Nayyar Parvez M. Fast dissolving oral film: a novel and innovative drug delivery system. Int J of Pharm Sci and Res. 2014;5(3): 92-5. 10. Arun A, Chandra A, Sharma V, Pathak K. Fast dissolving oral films: an innovative drug delivery system and dosage form. Int J Chemtech Res. 2010;2(1): 576-583.

11. Alka Tomar, Kiran Sharma, Nitesh S Chauhan, Ashu Mittal, Umakant Bajaj. Formulation and evaluation of fast

dissolving oral film of Dicyclomine as potential route of buccal delivery. Int J Drug Dev \& Res. 2012;4 (2): 408-417. 12. Sharma R, Parikh RK, Gohel MC, Soniwala MM. Development of taste masked film of valdecoxib for oral use. Indian J Pharm Sci. 2007;69 (2): 320-323.

13. Cilruzo F, Cupone El, Minghetti P, Buratti S, Chiara G.M. Gennari, Montanari L. Diclofenac fast-dissolving film: suppression of bitterness by a taste-sensing system. Drug Dev Ind Pharm. 2011;37(3): 252-259. Available from: http:// dx.doi.org/10.3109/03639045.2010.505928

14. Gavaskar Basani, Kumar Subash Vijaya, Guru Sharan, Rao Y Madhusudan. Overview on fast dissolving films. Int J Pharm Pharm Sci. 2009;2(3): 2933.

15. Aggarwal Jyoti, Singh Gurpreet, Saini Seema, Rana AC. Fast dissolving oral films: a novel approach to oral drug delivery. Int Res J of Pharm. 2011;2(12): 69-74.

16. Gunjan Shrivastava, Pankaj Kumar Singh, Roshni Fatima Rizvi, Shailendra Kumar Singh. A novel approach for buccal drug delivery system - fast dissolving film. World Journal of Pharmacy and Pharmaceutical Sciences. 2015;4(10): 1744-1760.

17. Bhyan Bhupinder, Jangra Sarita. Formulation and evaluation of fast dissolving sublingual films of Rizatriptan Benzoate. Int J Drug Dev \& Res. 2012;4(1): 133-134.

18. Ali MS, Vijendar C, Kumar SD, Krishnaveni J. Formulation and evaluation of fast dissolving oral films of diazepam. J Pharmacovigilance. 2016;4 (3): 210.

19. Deepthi A, Venkateswara Reddy B, Navaneetha K. Formulation and evaluation of fast dissolving oral films of Zolmitriptan. American Journal of Advanced Drug Delivery. 2014;2(2): 153-163.

20. Koland M, Sandeep VP, Charyulu NR. Fast dissolving sublingual films of ondansetron hydrochloride: effect of additives on in vitro drug release and mucosal permeation. $\mathrm{J}$ Young Pharm. 2010;2 (3): 216-222.

21. Hema Chaudhary, Samita Gauri, Permender Rathee, Vikash Kumar. Development and optimization of fast dis-

ISSN 2312-0967. Фармацевтичний часопис. 2017. № 2 
solving oro-dispersible films of granisetron $\mathrm{HCl}$ using BoxBehnken statistical design. Bulletin of Faculty of Pharmacy, Cairo University. 2013;51(2): 193-201.

22. Hrynovets IS, Kalynyuk TH, Melnyk YuYa, Suberlyak $\mathrm{OV}$. The study of deformation and mechanical properties of dental medical polymer type film. Farmats. zhurnal. 2009;5: 123-128. Ukrainian.

23. Available from: http://www.in-pharmatechnologist.com/ Ingredients/BioProgress-uses-films-in-drug-delivery

24. Prasanna Kumar Desu, B Brahmaiah, A Nagalakshmi, K Neelima, Sreekanth Nama, Chandu Baburao. An overview on rapid dissolving films. Asian J Pharm Res 2013;3(1): 15-23.
25. Available from: http://ddm.staging01.azuragroup. com/@offers/dds/view/905

26. Available from: http://www.monosolrx.com/products. html

27. Available from: http://www.tesa-labtec.com/eng

28. Available from: https://medicalxpress.com/news/200705-students-oral-quick-dissolve-rotavirus-vaccine.html 29. Available from: http://www.smilox.com/smile/ora-filmpain-relief-strips-6pk.cfm

30. Available from: http://www.monosolrx.com/advantages.html

31. Available from: http://www.helikon.com.tr/strip.asp

32. Available from: http://www.odftechnologies.com

Отримано 10.05.2017 